\title{
NERITIDAE (GASTROPODA, NERITIMORPHA) FROM THE MALACOLOGICAL COLLECTION PROF HENRY RAMOS MATTHEWS OF THE UNIVERSIDADE FEDERAL DO CEARÁ, BRAZIL
}

\author{
Neritidae (Gastropoda, Neritimorpha) depositados na \\ Coleção Malacológica Prof. Henry Ramos Matthews da \\ Universidade Federal do Ceará, Brasil
}

\author{
Cristiane Xerez Barroso', Cristina de Almeida Rocha Barreira ${ }^{2,3}$, \\ Helena Matthews-Cascon ${ }^{3,4}$
}

\author{
${ }^{1}$ Laboratory Technician at Laboratório de Invertebrados Marinhos do Ceará,Departamento de Biologia, \\ Centro de Ciências, Universidade Federal do Ceará, Fortaleza, CE, Brazil. E-mail: barrosocx@ufc.br \\ 2 Professor at Instituto de Ciências doa Mar (Labomar), Universidade Federal do Ceará, Fortaleza, CE, Brazil. \\ E-mail: cristina.labomar@gmail.com \\ ${ }^{3}$ Programa de Pós-Graduação em Ciências Marinhas Tropicais, Instituto de Ciências do Mar (Labomar), \\ Universidade Federal do Ceará, Fortaleza, CE, Brazil \\ ${ }^{4}$ Professor at Departamento de Biologia, Universidade Federal do Ceará, Fortaleza, CE, Brazil. \\ E-mail: helenamc@gmail.com
}

\begin{abstract}
The basic information obtained from scientific collections help us to understanding of Earth's diverse biota and its biological processes. The Malacological Collection Prof. Henry Ramos Matthews (CMPHRM) of the Universidade Federal do Ceará (UFC), Brazil, is a reference about the biodiversity, mainly marine, of northeastern Brazil. In this collection, the gastropod molluscs of the family Neritidae were among the most representative in number of lots. Since an accurate geographical distribution knowledge is one of the fundamental factors to the study of biodiversity, the present study aimed to describe the composition and spatially analyse the neritids deposited in the CMPHRM/UFC. There is a total of 314 lots of the Neritidae deposited at CMPHRM, belonging to eight species (Nerita chamaeleon, Nerita chlorostoma, Nerita fulgurans, Nerita tessellata, Neritina virginea, Neritina meleagris, Neritina zebra, and Smaragdia viridis). The Malacological Collection Prof. Henry Ramos Matthews of the Universidade Federal do Ceará has representatives of all species of
\end{abstract}

Recebido em: 20/01/2021

Aprovado em: 10/06/2021

Publicado on-line em: 20/12/2021 
Neritidae recorded in the Brazilian Province, which are important for confirming previous records or establishing new occurrence records.

Keywords: Neritina, Nerita, Smaragdia, Brazilian Province.

\section{RESUMO}

Informações básicas obtidas a partir de coleções científicas nos ajudam a entender a diversidade biótica da Terra e seus processos biológicos. A Coleção Malacológica Prof. Henry Ramos Matthews (CMPHRM) da Universidade Federal do Ceará (UFC), Brasil, é uma referência sobre a biodiversidade, principalmente marinha, do Nordeste do Brasil. Nessa coleção, os moluscos gastrópodes da família Neritidae estão entre os mais representativos em números de lotes. Desde que um acurado conhecimento da distribuição geográfica é um dos fatores fundamentais para o estudo da biodiversidade, o presente estudo teve como objetivos descrever a composição e analisar espacialmente os neritídeos depositados na CMPHRM/UFC. Existe um total de 314 lotes de Neritidae depositados na CMPHRM, pertencentes a oito espécies (Nerita chamaeleon, Nerita chlorostoma, Nerita fulgurans, Nerita tessellata, Neritina virginea, Neritina meleagris, Neritina zebra $e$ Smaragdia viridis). A Coleção Malacológica Prof. Henry Ramos Matthews (CMPHRM) da Universidade Federal do Ceará possui representantes de todas as espécies de Neritidae registradas para a Província Brasileira, que são importantes para confirmar registros pretéritos ou estabelecer novas ocorrências.

Palavras-chave: Neritina, Nerita, Smaragdia, Província Brasileira.

\section{INTRODUCTION}

The basic information that can be obtained from specimens and collections-based research help us to understanding of Earth's diverse biota and its biological processes (Rocha et al., 2014). Such knowledge, with its temporal and spatial dimensions, has also proven fundamental in conservation and management efforts (Rocha et al., 2014).

The Malacological Collection Prof. Henry Ramos Matthews (CMPHRM) of the Universidade Federal do Ceará (UFC), Brazil, was founded in 1966 and is a reference about the biodiversity, mainly marine, of northeastern Brazil (Rocha-Barreira; Matthews-Cascon \& Rabay, 2016). Currently, the CMPHRM consists of two series: Series A, located at the Zoobentos Laboratory of the Instituto de Ciências do Mar (Labomar/UFC), under the responsibility of dra. Cristina de Almeida Rocha Barreira, and Series B, at the Laboratório de Invertebrados Marinhos do Ceará (LIMCE) of the Departamento de Biologia (UFC), under the responsibility of dra. Helena Matthews-Cascon. Considering the 208 families represented in this collection, Neritidae was among the most representative in number of lots (Rocha-Barreira; Matthews-Cascon \& Rabay, 2016).

The neritid gastropods (Neritidae) are the most common members of Neritimorpha (Kano; Chiba \& Kase, 2002), having globose shell with few whorls, short spire, columella forming transversal septum, calcareous operculum, and rhipidoglossate radula (Russell, 
1941; Ponder \& Lindberg, 1997). Neritidae is found in the intertidal and supralittoral zones of rocky shores and mangroves, from the tropics to the temperate zones (e.g., Nerita), as well as brackish and freshwater systems (such as Theodoxus, Clithon, Neritina, and Septaria), or even associated with marine angiosperms (e.g., Smaragdia) (Flores \& Cáceres, 1973; Haynes, 1988; Matthews-Cascon; Pinheiro \& Matthews, 1990; Tan \& Clements, 2008; Quintero-Galvis \& Castro, 2013).

Since an accurate knowledge about the geographical distribution of species is one of the fundamental factors to the study of biodiversity (Wheeler; Raven \& Wilson, 2004), the present study aimed to describe the composition and spatially analyse the neritids deposited in the Malacological Collection Prof. Henry Ramos Matthews (CMPHRM/UFC).

\section{MATERIAL AND METHODS}

The composition and geographic distribution data of the neritids were obtained by analyzing the digital spreadsheets containing the information of each lot deposited at the CMPHRM/UFC.

The identifications of all specimens were reviewed with the aid of specific bibliographies (e.g., Rios, 2009; Eichhorst, 2016). The main characters used for identification included shape, surface ornamentation, and colour patterns of shells and opercula.

\section{RESULTS AND DISCUSSION}

There is a total of 314 lots of the Neritidae deposited at CMPHRM (93 lots from Series A and 221 lots from Series B), belonging to eight species [Nerita chlorostoma Lamarck, 1816; Nerita tessellata Gmelin, 1791; Nerita fulgurans Gmelin, 1791; Nerita chamaeleon Linnaeus, 1758; Neritina zebra (Bruguière, 1792); Neritina virginea (Linnaeus, 1758); Neritina meleagris Lamarck, 1822; and Smaragdia viridis (Linnaeus, 1758)], collected between the years 1958 and 2018 (Figure 1).

With the exception of three lots (one in Series A and two in Series B, totaling 10 shells from the Philippines) of Nerita chamaeleon, a species that occurs in the Indo-West Pacific (Frey \& Vermeij, 2008), all other lots analyzed are from Brazil, representing all seven species of Neritidae already recorded in the Brazilian Province (N. chlorostoma, N. fulgurans, N. tessellata, N. virginea, N. meleagris, N. zebra, and S. viridis) (Matthews-Cascon; Pinheiro \& Matthews, 1990; Baker, 1923; Rios, 1975, 1985, 1994, 2009; Matthews \& Rios, 1967a,b; Matthews \& Kempf, 1970; Russell, 1941; Mienis, 1991b; Díaz \& Puyana, 1994; Prado, 1998; Barroso; Matthews-Cascon \& Simone, 2012; Barroso et al., 2016; Barroso; Lotufo \& Matthews-Cascon, 2016; Eichhorst, 2016; Barroso et al., 2020). The Brazilian Province is a biogeographical area that extends from mouth of the Amazon river and Santa Catarina, Southeastern Brazil, also including insular areas (São Pedro and São Paulo Archipelago, Rocas Atoll, Fernando de Noronha Archipelago, and Vitória-Trindade seamount chain) (Floeter et al., 2008; Briggs \& Bowen, 2012; Barroso; Lotufo \& Matthews-Cascon, 2016) (Figure 2). We should point out that, although Eichhorst (2016) classifies N. zebra, N. virginea, and $N$. meleagris as belonging to the genus Vitta, differing Vitta from Neritina based on shell and opercular characters, Vitta is maintained as a subgenus in the phylogenetic analysis performed by Holthuis (1995). Since there is still a lack of phylogenetic confirmation to support Eichhorst's classification, we opted to the traditional classification (Neritina). 
Figure 1 - Species of Neritidae deposited at Malacological Collection Prof. Henry Ramos Matthews (CMPHRM) of the Universidade Federal do Ceará (UFC), Brazil. A. Nerita chlorostoma Lamarck, 1816 (CMPHRM 2774B); B. Nerita tessellata Gmelin, 1791 (CMPHRM 203B); C. Nerita fulgurans Gmelin, 1791 (CMPHRM 4017B); D. Nerita chamaeleon Linnaeus, 1758 (CMPHRM 2157B); E. Neritina zebra (Bruguière, 1792) (CMPHRM 2756B); F. Neritina virginea (Linnaeus, 1758) (CMPHRM 6410B); G. Neritina meleagris Lamarck, 1822 (CMPHRM 6462B); H. Smaragdia viridis (Linnaeus, 1758) (CMPHRM 4577B). Scale bars: $1.0 \mathrm{~cm}(\mathrm{~A}-\mathrm{G}), 1.0 \mathrm{~mm}(\mathrm{H})$

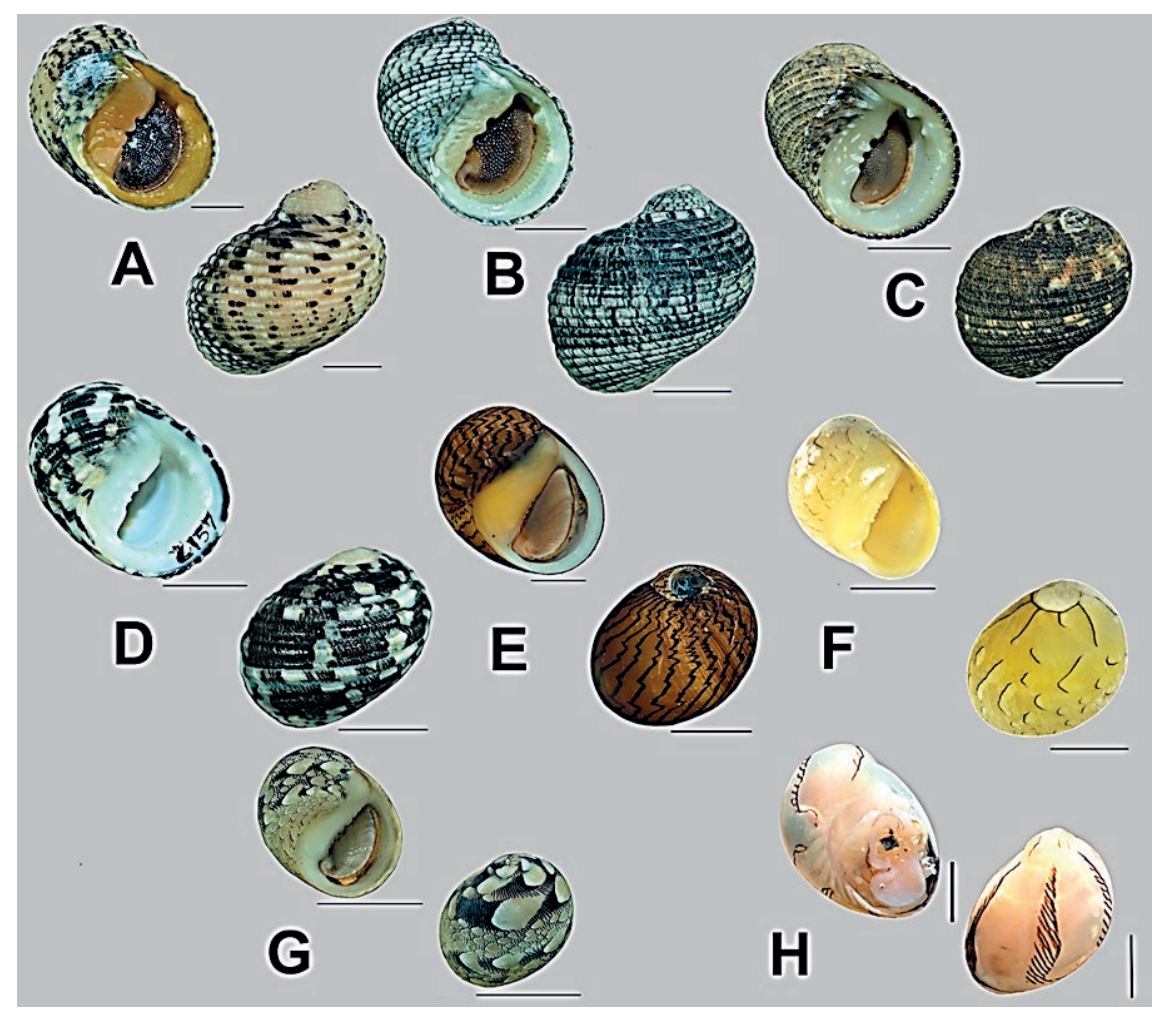

Photos: João Eduardo Pereira de Freitas 
Figure 2 - Location of the Brazilian Province (blue line), Western South Atlantic Ocean [biogeographical unit delimited according to the studies of Floeter et al. (2008), Briggs \& Bowen (2012), and Barroso; Lotufo \& Matthews-Cascon (2016)]. The numbers and acronyms correspond to regions (Brazilian States and insular areas) along Brazilian Province: 1. São Pedro and São Paulo Archipelago; 2. Rocas Atoll; 3. Fernando de Noronha Archipelago; 4. Trindade and Martin Vaz islands (part of Vitória-Trindade seamount chain); PA - Pará; MA Maranhão; PI - Piauí; CE - Ceará; RN - Rio Grande do Norte; PB - Paraíba; PE - Pernambuco; AL - Alagoas; SE Sergipe; BA - Bahia; ES - Espírito Santo; RJ - Rio de Janeiro; SP - São Paulo; PR - Paraná; and SC - Santa Catarina

Source: adapted from Barroso, Lotufo and Matthews-Cascon (2016).

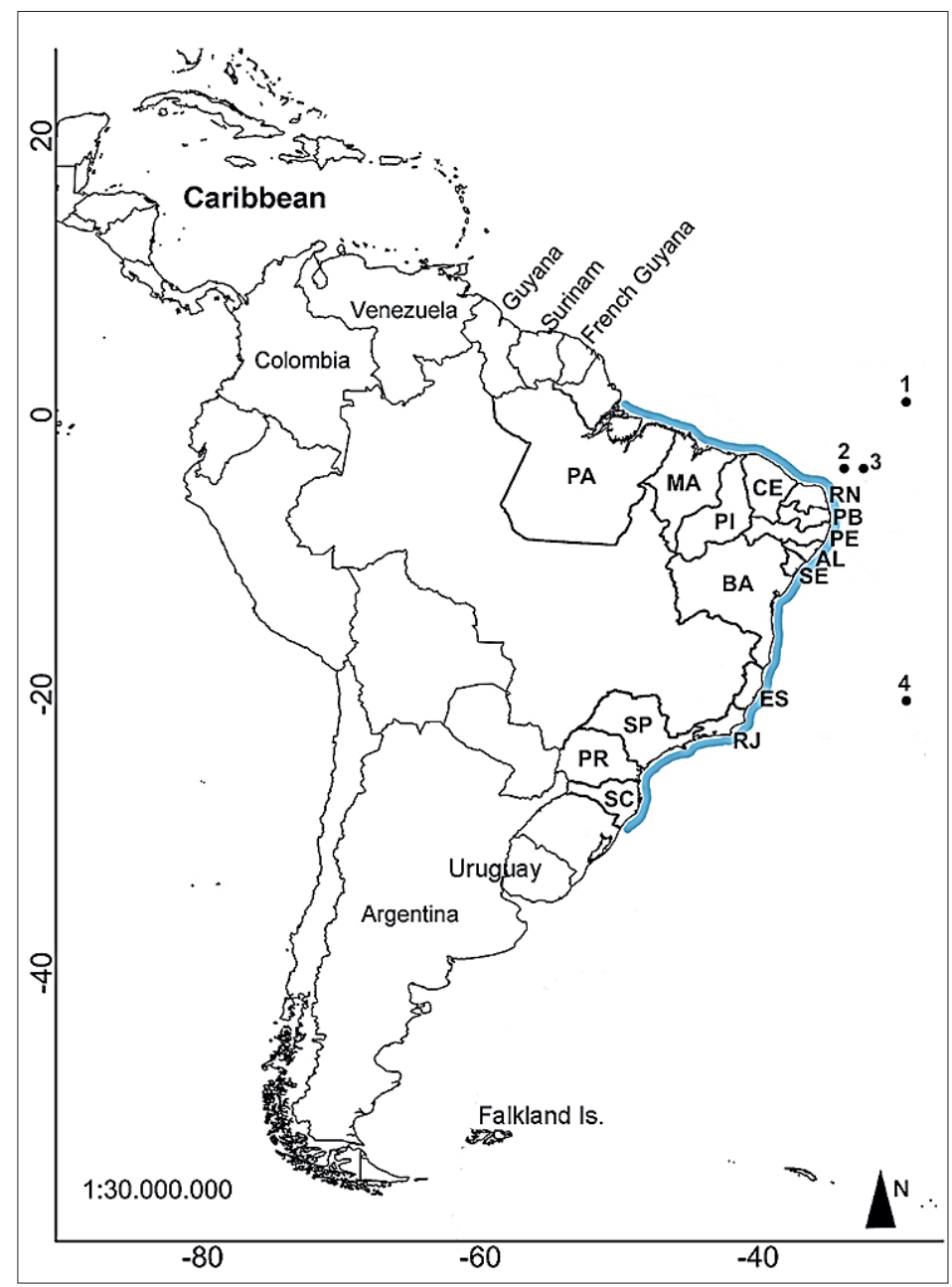

Of the 311 lots originating in Brazil, 277 (89\%) are from the Northeast region (Maranhão, Piauí, Ceará, Rio Grande do Norte, Paraíba, Pernambuco, and Bahia States), nine $(2.9 \%)$ from the North region (Pará State), four $(1.4 \%)$ from the Southeast region (Rio de Janeiro State) and 21 (6.8\%) from Brazilian oceanic islands (Rocas Atoll, Fernando de Noronha Archipelago, and Trindade Island).

Regarding the geographic distribution of the neritid species found in the Brazilian Province and deposited in the CMPHRM, with the exception of N. chlorostoma, all species occur in the coastal area, mainly in the intertidal region. Nerita chlorostoma is an endemic species of island environments of the Brazilian Province (Rocas Atoll, Fernando de Noronha Archipelago, and Trindade Island), inhabiting intertidal rocks (Lopes \& Alvarenga, 1955; Vermeij, 1970; Mienis, 1991a; Barroso et al., 2016; Eichhorst, 2016). In the CMPHRM, we found specimens and empty shells of $N$. chlorostoma from the three insular areas [one lot from Rocas Atoll, 18 from Fernando de Noronha Archipelago, and two from Trindade Island].

The other two Nerita species that occur in Brazilian Province - N. fulgurans and N. tessellata - are represented in the CMPHRM, respectively, by 21 and four lots (specimens and empty shells), from Piauí, Ceará, and Rio Grande do Norte (NE Brazil) for both species. As $N$. chlorostoma, N. fulgurans and $N$. tessellata are also found on intertidal rocks. These 
species have quite similar geographical distribution, occurring in the Caribbean and Brazilian Provinces (Rios, 1975, 2009; Eichhorst, 2016). In the Brazilian Province, Rios (1975) recorded N. fulgurans in Pará, Maranhão, Piauí, Ceará, and Rio Grande do Norte (N-NE Brazil) and N. tessellata in Piauí State (NE Brazil). Eichhorst (2016) corroborated Rios (1975) and established as the southern limit of $N$. fulgurans the state of Rio Grande do Norte (NE Brazil); while N. tessellata southern limit is Piauí State (NE Brazil). Two specimens of N. tessellata were collected in Maracajaú (Rio Grande do Norte State, NE Brazil) in 1979 (CMPHRM, 203B). This record expands the know distribution range (southern limit) for this species by approximately $750 \mathrm{~km}$. However, in a field collection for Maracajaú carried out in 2018, the presence of N. tessellata was not recorded. Matthews-Cascon, Pinheiro and Matthews (1990) highlighted that this species is extremely rare in north, northeastern Brazil. The occurrence of $N$. tessellata in the Brazilian Province needs to be further studied.

Concerning to Neritina species found in the Brazilian Province and deposited in the CMPHRM, there are specimens and empty shells of Neritina zebra from Pará (eight lots) and Ceará (40 lots) States, with this species having the most restricted geographical distribution, occurring from French Guiana to southeastern Brazil (São Paulo State) (Barroso; MatthewsCascon \& Simone, 2012). Neritina zebra occurs in fresh or brackish waters, on intertidal rocks, mangrove roots, and muddy bottoms (Matthews-Cascon; Pinheiro \& Matthews, 1990; Rios, 2009; Barroso; Matthews-Cascon \& Simone, 2012; Eichhorst, 2016).

In the CMPHRM, the other two species of Neritina recorded in the Brazilian Province - N. virginea and N. meleagris - are represented, respectively, by 87 and 121 lots. These two species have been treated as a single species $(N$. virginea) in studies conducted on the Brazilian coast at least for the past three decades. Albeit $N$. meleagris is considered valid in several studies (e.g., Baker, 1923; Russell, 1941; Rios, 1975; Matthews-Cascon; Pinheiro \& Matthews, 1990; Díaz \& Puyana, 1994; Quintero-Galvis \& Castro, 2013; Eichhorst, 2016), a widely cited references used in Brazil - the shell catalogues of Rios (1985, 1994, 2009) consider $N$. meleagris a junior synonym of $N$. virginea. In a recent study, using a molecular approach, Barroso et al. (2020) confirmed the existence of these two species (N. meleagris and N. virginea) on the Brazilian Province, corroborated with previous morphological studies (e.g., Matthews-Cascon; Pinheiro \& Matthews, 1990; Eichhorst, 2016). Barroso et al. (2020) highlighted the importance of the separation of these species in future studies, since them may cohabit. Thus, the records of N. virginea and N. meleagris on the Brazilian Province need to be updated.

At CMPHRM, there are specimens and empty shells of $N$. virginea from northeast and southeast Brazil (Piauí, Ceará, Rio Grande do Norte, Paraíba, Bahia, and Rio de Janeiro States). According to Eichhorst (2016), this species is distributed from Florida to Brazil, including the Gulf of Mexico and Caribbean Province. Rios (2009), as previously mentioned, considered $N$. meleagris a junior synonym of $N$. virginea, established the Santa Catarina State (south Brazil) as the southern limit of this species in the Brazilian Province. The distribution range of this species, especially its southern limit, needs further investigation.

Regarding N. meleagris, there are specimens and empty shells from the north to southeast of Brazil (Maranhão, Piauí, Ceará, Rio Grande do Norte, Paraíba, Pernambuco, Bahia, and Rio de Janeiro States) deposited in the CMPHRM. According to Eichhorst (2016), this species is distributed from Central America (Belize) to Brazil (São Paulo State), including the Greater and Lesser Antilles. As N. virginea, the southernmost limit of this species needs to be further studied. 
The third neritid genus deposited in the CMPHRM and found in the Brazilian Province was Smaragdia, represented by $S$. viridis, an herbivorous species that eats marine angiosperms upon which it lives (Rueda et al., 2009; Cavalcante et al., 2019). At CMPHRM, there are specimens of $S$. viridis (nine lots) from northeast Brazil (Piauí and Ceará States). In the Brazilian Province, this species was already recorded in Piauí (Barra Grande Beach), Ceará, Paraíba (Formosa beach), Bahia (Itaparica Island), and São Paulo (Porchat Island) (Rios, 2009; Rocha-Barreira et al., 2017; Cavalcante et al., 2019). According to Eichhorst (2016) and WoRMS data (WOrMS Editorial Board 2020), S. viridis is an amphi-atlantic species, occurring from Florida (USA) to Brazil, including Caribbean, in the Western Atlantic and from the Canary Islands to Senegal, comprising the Mediterranean in the Eastern Atlantic. Holzer, Rueda and Mcglathery (2011) demonstrated that S. viridis feeds preferentially on three common seagrass species in the Caribbean and Bermuda (Thalassia testudinum König, Halodule wrightii Ascherson, and Syringodium filiforme Kützing) and suggested a possible trophic dependence. All specimens in the CMPHRM were found associated with $H$. wrightii. Since this marine angiosperm species has a wide geographical distribution in the Brazilian Province (from Piauí to Santa Catarina) (Copertino et al., 2016), we believe that $S$. viridis has a geographic range quite similar to $H$. wrightii. We would also like to highlight that this species may be misidentified as young specimens of $N$. virginea or $N$. meleagris, as highlighted by Rios (2009), since S. viridis is a small and lesser-known species when compared to other neritids observed on the Brazilian Province.

The Malacological Collection Prof. Henry Ramos Matthews of the Universidade Federal do Ceará has representatives of all species of Neritidae recorded in the Brazilian Province, which are important for confirming previous records, establishing new occurrence records (in the case of $N$. tessellata) or reviewing geographical distribution data (in the case of $N$. meleagris and $N$. virginea). Thus, the CMPHRM has a great for reporting the diversity of Brazilian Province molluscs, especially in the Northeast Area. Biological collections are testimony of biodiversity and an indispensable support for systematic and taxonomic studies, being the dissemination of their collections an important tool for sharing the knowledge on biodiversity.

Acknowledgements - The Coordenação de Aperfeiçoamento de Pessoal de Nível Superior (Capes) provided a postdoctoral fellowship to C. X. Barroso (PNPD process number 88882.306440/2018-01). The authors wish to thank the photographer João Eduardo Pereira de Freitas for the images of the species used in this study.

\section{REFERENCES}

Baker, H.B. Notes on the radula of the Neritidae. J. Proceedings Acad. Nat. Sci. Philadelphia, v. 75 , p. 117-178, 1923.

Barroso, C.X.; Lotufo, T.M.C.; Bezerra, L.E.A. \& Matthews-Cascon, H. A biogeographic approach to the insular marine "prosobranch" gastropods from the southwestern Atlantic Ocean. J. Molluscan Stud., v. 82, p. 558-563, 2016. https:/ / doi.org/10.1093/mollus/ eyw015.

Barroso, C.X.; Lotufo, T.M.C. \& Matthews-Cascon, H. Biogeography of Brazilian prosobranch gastropods and their Atlantic relationships. J. Biogeogr., v. 43, n. 12, p. 24772488, 2016. https://doi.org/10.1111/jbi.12821. 
Barroso, C.X.; Matthews-Cascon, H. \& Simone, L.R.L.R.L. Anatomy of Neritina zebra from Guyana and Brazil (Mollusca: Gastropoda: Neritidae). J. Conchol., v. 41, n. 1, p. 49-64, 2012.

Barroso, C.X.; Freitas, J.E.P.; Matthews-Cascon, H.; Bezerra, L.E.A. \& Lotufo, T.M.C. Molecular evidences confirm the taxonomic separation of two sympatric congeneric species (Mollusca, Gastropoda, Neritidae, Neritina). Zookeys, v. 2020, n. 904, p. 117-130, 2020. https://doi.org/10.3897/zookeys.904.46790.

Briggs, J.C. \& Bowen, B.W. A realignment of marine biogeographic provinces with particular reference to fish distributions. J. Biogeogr., v. 39, n. 1, p. 12-30, 2012. https://doi. org/10.1111/j.1365-2699.2011.02613.x.

Cavalcante, L.L.; Barroso, C.X.; Carneiro, P.B.M. \& Matthews-Cascon, H. Spatiotemporal dynamics of the molluscan community associated with seagrass on the western equatorial Atlantic. J. Mar. Biol. Assoc. United Kingdom, v. 99, n. 6, p. 1285-1294, 2019. https://doi. org/10.1017/S0025315419000183.

Copertino, M.S.; Creed, J.C.; Lanari, M.O.; Magalhães, K.; Barros, K.; Lana, P.C.; Sordo, L. \& Horta, P.A. Seagrass and submerged aquatic vegetation (VAS) habitats off the coast of Brazil: State of knowledge, conservation and main threats. Brazilian J. Oceanogr., v. 64, n. 2, p. 53-80, 2016. https:/ / doi.org/10.1590/S1679-875920161036064sp2.

Díaz, J.M. \& Puyana, M. Moluscos del Caribe Colombiano: un catálogo ilustrado. Bogota: Colciencias y Fundacion Natura Colombia, 354 p., 1994.

Eichhorst, T.E. Neritidae of the World - Volume One. Hackenheim: ConchBooks, 694 p., 2016.

Floeter, S.R.; Rocha, L.A.; Robertson, D.R.; Joyeux, J.C.; Smith-Vaniz, W.F.; Wirtz, P.; Edwards, A.J.; Barreiros, J.P.; Ferreira, C.E.L.; Gasparini, J.L.; Brito, A.; Falcón, J.M.; Bowen, .W. \& Bernardi, G. Atlantic reef fish biogeography and evolution. J. Biogeogr., v. 35, p. 2247, 2008. https:/ / doi.org/10.1111/j.1365-2699.2007.01790.x.

Flores, C. \& Cáceres, R. La familia Neritidae (Mollusca: Archaeogastropoda) en las aguas costeras de Venezuela. Bol. del Inst. Oceanogr. Univ. Oriente, v. 12, p. 3-13, 1973.

Frey, M.A. \& Vermeij, G.J. Molecular phylogenies and historical biogeography of a circumtropical group of gastropods (Genus: Nerita): Implications for regional diversity patterns in the marine tropics. Mol. Phylogenet. Evol., v. 48, n. 3, p. 1067-1086, 2008. https:/ / doi.org/10.1016/j.ympev.2008.05.009.

Haynes, A. Notes on the stream neritids (Gastropoda; Prosobranchia) of Oceania. Micronesica, v. 21, p. 93-102, 1988.

Holthuis, B. Evolution between marine and freshwater habitats: a case study of the gastropod suborder Neritopsina. Tese de doutorado, University of Washington, 336 p., Seattle, 1995.

Holzer, K.K.; Rueda, J.L. \& Mcglathery, K.J. Caribbean Seagrasses as a Food Source for the Emerald Neritid Smaragdia viridis. Am. Malacol. Bull., v. 29, n. 1-2, p. 63-67, 2011. https:// doi.org/10.4003/006.029.0219.

Kano, Y.; Chiba, S. \& Kase, T. Major adaptive radiation in neritopsine gastropods estimated from $28 S$ rRNA sequences and fossil records. Proc. Biol. Sci., v. 269, n. 1508, p. 2457-2465, 2002. https:/ / doi.org/10.1098/rspb.2002.2178. 
Lopes, H. de S. \& Alvarenga, M. Contribuição ao conhecimento dos moluscos da Ilha de Fernando de Noronha - Brasil. Bol. do Inst. Ocean., v. 6, n. 1-2, p. 157-196, 1955.

Matthews-Cascon, H.; Pinheiro, P.R.C. \& Matthews, H.R. A família Neritidae no Norte e Nordeste do Brasil (Mollusca: Gastropoda). Caatinga, v. 7, p. 44-56, 1990.

Matthews, H.R. \& Kempf, M. Moluscos marinhos do Norte e Nordeste do Brasil. II Moluscos do Arquipélago de Fernando de Noronha (com algumas referências ao Atol das Rocas). Arq. Ciências do Mar, v. 10, n. 1, p. 1-53, 1970.

Matthews, H.R. \& Rios, E.C. Primeira contribuição ao inventário dos moluscos marinhos do Nordeste brasileiro. Arq. da Estação Biol. Mar da Univ. Fed. do Ceará, v. 7, n. 1, p. 67-77, 1967a.

Matthews, H.R. \& Rios, E.C. Segunda contribuição ao inventário dos moluscos marinhos do Nordeste brasileiro. Arq. Ciências do Mar, v. 7, n. 2, p. 113-121, 1967b.

Mienis, H.K. A nomenclatorial note concerning the Nerita ascensionis - complex. Siratus, v. 10, p. 13-17, 1991a.

Mienis, H.K. Neritina zebra and the variability of its colour pattern. Pallidula, v. 21, n. 2, p. 14-17, 1991b.

Ponder, W.F. \& Lindberg, D.R. Towards a phylogeny of gastropod molluscs: analysis using morphological characters. Zool. J. Linn. Soc., v. 119, n. 2, p. 83-265, 1997. https://doi. org/10.1006/zjls.1996.0066.

Prado, A.C.G. The family Neritidae Rafinesque, 1815 (Gastropoda: Neritoidea) in the Western Atlantic. Strombus, v. 2, p. 1-4, 1998.

Quintero-Galvis, J. \& Castro, L.R. Molecular phylogeny of the Neritidae (Gastropoda: Neritimorpha) based on the mitochondrial genes cytochrome oxidase I (COI) and $16 \mathrm{~S}$ rRNA. Acta Biológica Colomb., v. 18, n. 2, p. 307-318, 2013.

Rios, E.C. Marine Iconography. Rio Grande: Editora Fundação da Universidade do Rio Grande, 331 p., 1975.

Rios, E.C. Seashells of Brazil. Rio Grande: Editora Fundação Universidade do Rio Grande, 328 p., 1985.

Rios, E.C. Seashells of Brazil. Rio Grande: Editora Fundação da Universidade do Rio Grande, 331 p., 1994.

Rios, E.C. Compendium of Brazilian Sea Shells. Rio Grande: Editora Evangraf, 668 p., 2009.

Rocha-Barreira, C. de A.; Barros, K.V.S.; Matthews-Cascon, H.; Queiroz, L.R.; Silva, A.F. \& Barroso, C.X. Ecology of mollusc communities in marine environments: central region of the semiarid coast of Brazil, p. 165-208, in Jenkins, O.P. (ed.). Advances in Animal Sciience and Zoology, New York: Nova Science Publishers, 276 p., 2017.

Rocha-Barreira, C. de A.; Matthews-Cascon, H. \& Rabay, S.G. Coleção Malacológica Prof. Henry Ramos Matthews da Universidade Federal do Ceará: 50 anos de história e contribuições ao conhecimento dos moluscos do Nordeste brasileiro. Arq. Ciências do Mar, v. 49, p. 9-16, 2016.

Rocha, L.A.; Aleixo, A.; Allen, G.; Almeda, F.; Baldwin, C.C. \& Barclay, M.V.L. Specimen collection: an essential tool. Science, v. 344, n. 6186, p. 814-816, 2014. https://doi.org/10.1126/ science.344.6186.814. 
Rueda, J.L.; Salas, C.; Urra, J. \& Marina, P. Herbivory on Zostera marina by the gastropod Smaragdia viridis. Aquat. Bot., v. 90, n. 3, p. 253-260, 2009. https://doi.org/10.1016/j. aquabot.2008.10.003.

Russell, H.D. The recent mollusks of the family Neritidae of the Western Atlantic. Bull. Mus. Comp. Zool., v. 88, p. 347-404, 1941.

Tan, S.K. \& Clements, R. Taxonomy and distribution of the Neritidae (Mollusca: Gastropoda) on Singapore. Zool. Stud., v. 47, n. 4, p. 481-494, 2008.

Vermeij, G.J. The Nerita ascensionis Species Complex in the South Atlantic (Gastropoda: Prosobranchia). The Veliger, v. 13, n. 2, p. 135-138, 1970.

Wheeler, Q.D.; Raven, P.H. \& Wilson, E.O. Taxonomy: impediment or expedient? Science, v. 303, n. 5656, p. 285, 2004. https://doi.org/10.1126/science.303.5656.285.

WoRMS Editorial Board. World register of marine species. 2021. Available in: http:// www.marinespecies.org. Accessed in: 11 Jan. 2021. https:/ / doi.org/10.14284/170. 